\title{
Chemical Constituents of Malaysian Apis mellifera Propolis
}

(Juzuk Kimia Propolis Apis mellifera Malaysia)

\author{
TUAN NADRAH NAIM TUAN ISMAIL, SITI AMRAH SULAIMAN, KANNAN THIRUMULU PONNURAJ, \\ CHE NIN MAN \& NORUL BADRIAH HASSAN*
}

\begin{abstract}
Propolis is a resinous material collected by honey bees from various plant sources. The chemical constituents differ depending on the source of vegetation area. To date, no study of the chemical constituents of Apis mellifera propolis from Malaysia has been reported. Thus, the aim of this study was to determine the chemical constituents of Malaysian Apis mellifera propolis. Raw propolis samples were collected from Acacia mangium apiary from northern and southern regions of Peninsular Malaysia and were extracted using $70 \%$ ethanol. Then, the ethanolic extracts were evaporated and were lyophilized to dryness. The silylated compounds were identified by gas chromatography with mass spectrometry analysis (GC-MS). The compounds were characterised by comparison with NIST02 and Wiley275 libraries. Twenty-six individual compounds were identified and $\beta$-panasinsene was identified for the first time in propolis. The main compounds identified from both southern and northern regions of Peninsular Malaysia were terpenoids. Terpenoids belong to an important class in the propolis compounds due to its valuable biological properties. The amount of terpenoids ranged from 7.19 to $11.46 \%$ indicating that although the main plant source for both regions was Acacia mangium, other shrubs and fruit orchards surrounding the two apiaries may differ which may contribute to the variations.
\end{abstract}

Keywords: Ethanolic extract; GC-MS; Malaysian propolis

\section{ABSTRAK}

Propolis adalah bahan resin yang dipungut oleh lebah madu daripada pelbagai sumber tumbuh-tumbuhan. Juzuk kimia berbeza bergantung kepada sumber kawasan tumbuh-tumbuhan. Sehingga kini, tiada kajian juzuk kimia propolis Apis mellifera dari Malaysia dilaporkan. Justeru, tujuan kajian ini adalah untuk mengenal pasti kandungan kimia propolis Apis mellifera Malaysia. Sampel propolis mentah telah dikumpul dari tempat ternakan lebah Acacia mangium dari kawasan utara dan selatan Semenanjung Malaysia dan telah diekstrak menggunakan 70\% etanol. Kemudian, ekstrak etanol telah disejat dan dibeku keringkan. Sebatian sililasi telah dikenal pasti menggunakan analisis kromatografi gas dan jisim spektrometri (GC-MS). Sebatian dicirikan melalui perbandingan dengan perpustakaan NIST02 and Wiley275. Dua puluh enam sebatian individu telah dikenal pasti dan $\beta$-panasinsene telah dikenal pasti buat kali pertama daripada propolis. Sebatian utama yang dikenal pasti daripada kedua-dua kawasan selatan dan utara Semenanjung Malaysia adalah terpenoid. Jumlah terpenoid antara 7.19-11.46\% menunjukkan bahawa walaupun sumber tumbuhan utama untuk kedua-dua kawasan adalah Acacia mangium, tetapi pokok renek lain dan kebun buah-buahan di sekitar dua apiari mungkin berbeza dan menyumbang kepada perbezaan.

Kata kunci: Ekstrak etanol; GC-MS; propolis Malaysia

\section{INTRODUCTION}

Propolis is one of the bee products consists of a mixture of resinous substances collected by honey bees from various plant sources, mainly from flowers and leaf buds and mixed with their saliva (Bankova et al. 2000; Marcucci 1995).

It is used to patch small holes in the beehives, to strengthen the borders of combs, to line all cells inside and balancing humid conditions or extreme drought. In addition, propolis is also used to embalm dead animals or insects that cannot be expelled by the honey bees (Ghisalberti 1979). Propolis comes from the ancient Greek words; "pro" and "polis". Pro is before and polis is city, meaning before the city or defender of the city. Propolis means a substance to defence the beehive. Propolis has been widely used in ancient remedies as early as $300 \mathrm{BC}$ due to its various biological properties.

Propolis generally contains $45-55 \%$ resins which comprise of flavonoids, phenolic acids and their esters, 25$35 \%$ waxes and fatty acids, $10 \%$ essential oils (volatiles), $5 \%$ pollens and 5\% minerals (Krell 1996). More than 300 chemical compounds were identified so far (Huang et al. 2014).

Chemical compounds of propolis is different based on the vegetation at the area from which it was collected (Bankova 2005). The main plant sources of propolis from temperate zones were poplar and birch tree (Roumen et al. 2006). On the other hand, conifer species of the Cupressaceae family were the main botanical source of 
propolis from Mediterranean regions (Popova et al. 2012). The study of propolis from tropical rainforest climate especially Brazil showed that Baccharis dracunculifolia and Dalbergia ecastaphyllum were the main botanical origin (Dausghch 2008; Park 2004). Investigation of propolis from tropical Asia discovered Macaranga tanarius L. and Mangifera indica L. as the plant sources of the Indonesian propolis (Trusheva et al. 2011).

The main compounds of propolis from temperate zone (Europe, North America and non-tropic Asia) were flavonoids aglycones, phenolic acids and their esters (Maciejewicz et al. 2001; Hegazi et al. 2000). In contrast, the major compounds of propolis from tropical rainforest climate (Southeast Asia, Central Africa and South America) especially Brazil were artepillin C (Park et al. 2004) and prenylflavonones from Indonesian propolis (Trusheva et al. 2011). Whereas the main compounds of propolis from Mediterranean were terpenoids and sugars (Popova et al. 2011).

Literature survey showed that phenolic compounds, flavonoids and terpenoids were attributed to the biological activities of propolis. Propolis is well known to have various biological activities such as antibacterial (Boonsai et al. 2014), antifungal (Agüero et al. 2014), antiviral (Yildirim et al. 2016), anti-inflammatory (Machado et al. 2012; Naito et al. 2007), antioxidant (Ahn et al. 2007, 2004; Shiva et al. 2007), antitumour (Sobočanec et al. 2011; Xuan et al.2014), hepatoprotective (Banskota et al. 2001; Paulino et al. 2014), neuroprotective (Nakajima et al.2007; Shimazawa et al. 2005), anti-diabetic (Zhu et al. 2011), anti-amnesia (Chen et al. 2008), local anaesthesia (Paintz \& Metzner 1979), antiulcer (de Barros et al.2008) and UV light protection (Cole et al. 2010; Gregoris et al. 2011).

Malaysia is a tropical country blessed with wide range of plant species and hence the chemical constituents of Malaysian propolis should be different with propolis produced in other regions. Numerous studies on biological properties of Malaysian propolis investigated have revealed that propolis has the potential to assist in wound healing (Jacob et al. 2015), antifungal (Nik Yusliyana et al. 2016), antioxidant (Zayyanu Usman et al. 2016a) and antidiabetic (Zayyanu Usman et al. 2016b) activities. Few studies on chemical compounds in Malaysian propolis have been carried out which have shown a range of volatile and nonvolatile compounds (Nurhamizah et al. 2016; Nur Liyana et al. 2016; Zayyanu Usman et al. 2016a; Zayyanu Usman \& Mahaneem 2015). However, these studies focused on propolis from stingless bees or Trigona spp. To date, no study has been reported on the analysis of chemical compounds in Malaysian propolis from Apis mellifera bees. Therefore, this study aimed to identify the various chemical constituents of propolis derived from Apis mellifera bees cultured in Acacia mangium apiary from northern and southern regions of Peninsular Malaysia.

\section{MATERIALS AND METHODS}

PROPOLIS SAMPLE

Two samples of raw Apis mellifera propolis, one from the northern and the other from the southern region of Peninsular Malaysia from Acacia mangium apiary were used in the current study. $250 \mathrm{~g}$ each of the pooled propolis samples collected from numerous beehives were supplied by the Malaysian Department of Agriculture, which were stored at $-20^{\circ} \mathrm{C}$ until use.

\section{PREPARATION OF ETHANOLIC EXTRACT OF PROPOLIS}

The extracts were prepared based on the methods described by Krell (1996) with some modifications. Propolis samples were cooled in a freezer $\left(-20^{\circ} \mathrm{C}\right)$ for a day and were ground into a fine powder. Then, $50 \mathrm{~g}$ of each propolis sample was mixed with $167 \mathrm{mg}$ of $70 \%$ ethanol to obtain $30 \%(\mathrm{w} / \mathrm{w})$ propolis extract. The mixture was shaken twice a day and was left for a week at room temperature. Then, the mixture was filtered two times through Whatman filter paper No. 1. Prior to the second filtration, the extract was kept in refrigerator $\left(2-8^{\circ} \mathrm{C}\right)$ in order to remove the wax. The ethanol was evaporated by using a rotary evaporator under vacuum at $35^{\circ} \mathrm{C}$. The remaining water in the extract was dried by using freeze dryer and the dry extract was stored in the amber glass and was put in the freezer $\left(-20^{\circ} \mathrm{C}\right)$.

\section{GC-MS ANALYSIS}

\section{SAMPLE PREPARATION FOR GC-MS}

The dried extract $(0.5 \mathrm{mg})$ was derivatised with $50 \mu \mathrm{l}$ MSTFA in a sealed glass tube for $30 \mathrm{~min}$ at $60^{\circ} \mathrm{C}$. The trimethylsilylated extract was cooled to room temperature before dilution with $50 \mu \mathrm{L}$ of dodecane. The extract was transferred into crimped cap vial before GC-MS analysis. Blank ethanol (negative control) was dried and treated similarly as the sample.

\section{GC-MS CONDITIONS AND PARAMETERS}

GC-MS was carried out using Hewlett Packard 6890 Gas Chromatograph with 5973N Mass Selective Detector. The column was fused silica capillary, HP-5 column (30 $\mathrm{m} \times 0.25 \mathrm{~mm}$ i.d $\times 0.25 \mu \mathrm{m}$ film thickness) (Agilent Technologies, USA). The carrier gas was helium with flow rate at $1.0 \mathrm{~mL} / \mathrm{min}$ with the oven temperature was programmed from $50^{\circ} \mathrm{C}$ (held for $2 \mathrm{~min}$ ) to $280^{\circ} \mathrm{C}$ (held for $10 \mathrm{~min}$ ) at a rate of $20^{\circ} \mathrm{C} / \mathrm{min}$. The injection and interface temperatures were set at $250^{\circ} \mathrm{C}$ and $280^{\circ} \mathrm{C}$, respectively.

One microliter sample was injected in splitless mode and analysed in MS full scan mode $(\mathrm{m} / \mathrm{z}$ 40-650). The electron ionization was fixed at $70 \mathrm{eV}$. Acquisition of data was performed using Chemsation software. 


\section{IDENTIFICATION OF THE CHEMICAL CONSTITUENTS}

Identification of chemical constituents was accomplished based on mass spectral matching with National Institute of Standards and Technology (NIST02) and Wiley275 libraries ( $\geq 80 \%$ matching). The concentration of the identified compound was computed based on the percentage of the relative peak area $(\%)$.

\section{RESULTS AND DISCUSSION}

The chemical constituents of EEP from northern and southern regions of Peninsular Malaysia, which were collected from Acacia mangium apiary, were investigated by GC-MS after silylation. Chemical compounds identified in this study include phenolic acids, fatty acids, terpenoids, sugars and their derivatives were similar with other propolis (Kartal et al. 2002).

Twenty-six individual compounds were identified and $\beta$-panasinsene was identified for the first time from propolis. Out of 26 chemical compounds, only 4 similar compounds were identified in both regions. The chemical constituents of EEP as \% of relative peak area are presented in Table 1. Although the propolis samples were collected from the same apiary, the difference of shrubs and fruit orchards around make the chemical compounds from two regions differs significantly.

The majority of identified compounds in EEP from northern and southern regions were terpenoids, which comprised of 11.46 and $7.19 \%$, respectively. This finding was similar with Apis mellifera propolis from other tropic region (Li et al. 2009) and Mediterranean area (Popova et al. 2011, 2010). Similar finding was observed from Trigona spp propolis from Malaysia (Usman et al. 2016). However, the terpenoid compounds were different. Only one compound was similar, namely delta cardine. In the present study, eleven compounds of terpenoids were identified. Out of 11 identified terpenoids compounds, only 3 compounds were identified from both regions which are aromadendrene, $\alpha$-cedrol and globulol. The main terpenoids compounds identified in propolis from

TABLE 1. Chemical compounds of ethanolic extracts of Malaysian Apis mellifera propolis

\begin{tabular}{|c|c|c|}
\hline \multirow[t]{2}{*}{ Compounds } & \multicolumn{2}{|c|}{ Relative peak area (\%) } \\
\hline & Northern region & Southern region \\
\hline \multicolumn{3}{|l|}{ Phenolic acids and esters } \\
\hline Gallic acid ${ }^{\mathrm{a}}$ & 0.91 & 1.39 \\
\hline Cinnamic acid ${ }^{\mathrm{a}}$ & & 0.07 \\
\hline \multicolumn{3}{|l|}{ Fatty acids and esters } \\
\hline Arachidic acid ${ }^{\mathrm{a}}$ & - & 1.22 \\
\hline Behenic acid $^{\mathrm{a}}$ & - & 1.06 \\
\hline Ethyl linoleatea ${ }^{a}$ & - & 0.20 \\
\hline Ethyl stearate $^{\mathrm{a}}$ & - & 0.12 \\
\hline Eicosanoic acid methyl ester ${ }^{\mathrm{a}}$ & 0.57 & - \\
\hline \multicolumn{3}{|l|}{ Terpenoids } \\
\hline Aromadendrene & 1.15 & 0.03 \\
\hline$\alpha$-cedrol & 1.04 & 0.48 \\
\hline$\alpha$-eudesmol & - & 0.13 \\
\hline Lupenone & - & 6.49 \\
\hline Globulol & 2.51 & 0.06 \\
\hline$\gamma$-gurjunene & 1.68 & - \\
\hline$\delta$-selinene & 2.41 & - \\
\hline Ledene & 1.47 & - \\
\hline$\delta$-cadinine & 0.14 & - \\
\hline$\beta$-panasinsene & 0.18 & - \\
\hline Epiglobulol & 0.88 & - \\
\hline \multicolumn{3}{|l|}{ Sugars and their Derivatives } \\
\hline Arabinofuranose $^{\mathrm{a}}$ & - & 0.49 \\
\hline D-fructose ${ }^{a}$ & - & 5.09 \\
\hline D-ribofuranose ${ }^{a}$ & 0.45 & - \\
\hline D-galactose ${ }^{a}$ & - & 0.18 \\
\hline Galacturonic acid ${ }^{\mathrm{a}}$ & 0.97 & - \\
\hline Glycerol $^{\mathrm{a}}$ & - & 1.16 \\
\hline xylitol $^{\mathrm{a}}$ & 0.17 & - \\
\hline Erythritol $^{\mathrm{a}}$ & - & 0.83 \\
\hline
\end{tabular}

${ }^{\mathrm{a}}=$ Compound identified without TMS (trimethylsilyl) group 
northern and southern regions were globulol and lupenone, respectively. Terpenoids are known to have antibacterial, antifungal (Melliou et al. 2007) and anticancer activities (Huang et al. 2012).

The other main class of propolis compounds was phenolic acids and their esters. The identified phenolic acids were gallic acid (3,4,5-trihydroxybenzoic acid) and cinnamic acid. Gallic acid was found in the propolis samples from both regions.

Fatty acids were the other compounds identified from propolis in the present study. Arachidic acid, behenic acid, ethyl linoleatea, ethyl stearate, eicosanoic acid methyl ester were the identified fatty acids in Malaysian Apis mellifera propolis.

The other main class of propolis compounds was sugars. Arabinofuranose, D-fructose, D-ribofuranose, D-galactose, galacturonic acid, glycerol, xylitol and erythritol were the identified sugars from propolis samples in the current study. The amount of sugars was ranged from 1.59 to $7.76 \%$. The high percentage of sugars indicates the plant source has high mucilage (Bankova et al. 2000). This finding was similar with propolis samples from Mediterranean (Popova et al. 2011, 2010) and tropic region in Asia; showed a significant amount of sugars and their derivatives (Syamsudin et al. 2009), range from 0.8 to $37.2 \%$.

Flavonoids were not identified from Malaysian propolis which was consistent with the findings of GC-MS analysis of propolis from tropic regions (Syamsudin et al. 2009) and Mediterranean regions (Popova et al. 2011, 2010) most probably due to their plant source. Acacia mangium and rainforest tree nearby might be the main plant source of propolis in the current study; while the main plant source of European propolis were poplar trees (Roumen et al. 2006; Toreti et al. 2013). Rainforest trees are rich in glycoside flavonoid which is very polar and might be not amenable to GC-MS, whereas poplar tree is rich in non-polar flavonoids aglycones. In contrast, other studies on Malaysian propolis showed the presence of flavonoids. However, the propolis samples were from Trigona spp bees and were analysed by thin layer chromatography (Nurhamizah et al. 2016) and Folin-Ciocalteu method (Zayyanu Usman et al. 2016b). The difference could be due to the bee species or analytical technique.

There are several methods to identify and quantify the chemical constituents of propolis. The method chosen are depending on the chemical nature of the interested propolis compounds. To identify the compounds, the mixture will be separated first, and then the compounds will be identified. $\mathrm{GC}$ is one of the great separation techniques using carrier gas as mobile phase. It is very effective, sensitive (can detect ppm), require small sample $(\mu \mathrm{l})$, accurate, fast analysis (typically minutes), quantitative and well known. A part of that, GC-MS has the advantages of higher chromatographic resolution and higher peak capacity, a single mobile phase (helium), fewer issues with solubility and separations that can be adjusted by electronic controls such as temperature and flow programming (Hübschmann 2015).
However, GC has few weaknesses such as the sample must be volatile, heat-stable and need experience and training (McNair \& Miller 2011). The limitations of GC can be overcome by derivatising the samples to increase their volatility and thermal stability. In the current study, propolis extract was derivatised by using silylation reaction. Mass spectrometer is the most widely used detector for GC in propolis analysis. Identification of compounds is based on mass spectrum. Mass spectrum produced by a given chemical compound is basically the same every time. Therefore, the mass spectrum is essentially a fingerprint for the compounds. The mass spectrum of the each compound can be compared by mass spectra library to identify unknown compounds.

Many studies have analysed the propolis compounds using GC-MS (Murat 2002; Maciejewicz et al. 2001; Park et al. 2002) and HPLC methods (Osmany et al. 2007; Medana et al. 2008; Volpi \& Bergonzini 2006) since the propolis compounds has varied polarity.

Ideally, non-polar or volatile compounds are easier to analyse by GC-MS, whereas for identification of polar or non-volatile compounds, HPLC is better. However, derivatisation can increase the volatility and polarity of the compounds, thus make the compounds amenable to GC-MS analysis. Compared to HPLC, GC-MS is more potent and providing a general view of propolis compounds (Garcia-Viguera et al. 1993; Marquez Hernandez et al. 2010). GC-MS analysis of propolis showed this technique able to identify flavonoids, phenolic acid and their esters, aromatic compounds, fatty acids, terpenoids, essential oils and sugars. However, for the specific analysis of the phenolic compounds, HPLC with PDA is more useful (Garcia-Viguera et al. 1993). Therefore, GC-MS technique was chosen to identify the overall view of propolis in this research since of the study on Apis mellifera propolis from Malaysia is still lacking. Further, quantitative analysis for each identified compound is needed to establish the criteria for the quality control of national propolis samples.

\section{ACKNOWLEDGEMENTS}

The authors would like to thank Universiti Sains Malaysia for providing financial support under Short Term Grant, (304/PPSG/61312066), Mr. Zakbah b. Mian from Department of Agriculture, Johor, Malaysia and Mdm. Rohaya from MTC Advance Marketing Sdn Bhd, Penang, Malaysia for supplying propolis samples and Assoc. Prof Tan Soo Choon from Institute for Research in Molecular Medicine, Universiti Sains Malaysia, Pulau Pinang, Malaysia for helping in GC-MS analysis.

\section{REFERENCES}

Agüero, M.B., Svetaz,L., Baroni, V.,Lima, B., Luna, L., Zacchino, S., Saavedra, P., Wunderlin, D., Feresin, G.E. \& Tapia, A. 2014. Urban propolis from San Juan province (Argentina): Ethnopharmacological uses and antifungal activity against Candida and dermatophytes. Industrial Crops and Products 57: 166-173. 
Ahn, M-R., Kumazawa, S., Usui, Y., Nakamura, J., Matsuka, M., Zhu, F. \& Nakayama, T. 2007. Antioxidant activity and constituents of propolis collected in various areas of China. Food Chemistry 101(4): 1383-1392.

Ahn, M-R., Kumazawa, S., Hamasaka, T., Bang, K-S. \& Nakayama, T. 2004. Antioxidant activity and constituents of propolis collected in various areas of Korea. Journal of Agricultural and Food Chemistry 52(24): 7286-7292.

Bankova, V. 2005. Chemical diversity of propolis and the problem of standardization. Journal of Ethnopharmacology 100(1): 114-117.

Bankova, V.S., de Castro, S.L. \& Marcucci, M.C. 2000. Propolis: Recent advances in chemistry and plant origin. Apidologie 31(1): 3-16.

Banskota, A.H., Tezuka, Y., Adnyana, I.K., Ishii, E., Midorikawa, K., Matsushige, K. \& Kadota, S. 2001. Hepatoprotective and anti-helicobacter pylori activities of constituents from Brazilian propolis. Phytomedicine 8(1): 16-23.

Boonsai, Pattaraporn, Preecha Phuwapraisirisan \& Chanpen Chanchao. 2014. Antibacterial activity of a cardanol from Thai Apis mellifera propolis. International Journal of Medical Sciences 11(4): 327-336.

Chen, J., Long, Y., Han, M., Wang, T., Chen, Q. \& Wang, R. 2008. Water-soluble derivative of propolis mitigates scopolamine-induced learning and memory impairment in mice. Pharmacology Biochemistry and Behavior 90(3): 441-446.

Roumen Christov, Boryana Trusheva, Milena Popova, Vassya Bankova \& Michel Bertrand. 2006. Chemical composition of propolis from Canada, its antiradical activity and plant origin. Natural Product Research 20(06): 531-536.

Cole, N., Sou, P.W., Ngo, A., Tsang, K.H., Severino, J.A.J., Arun, S.J., Duke, C.C. \& Reeve, V.E. 2010. Topical 'Sydney' propolis protects against UV-radiation-induced inflammation, lipid peroxidation and immune suppression in mouse skin. International Archives of Allergy and Immunology 152(2): 87-97.

de Barros, M.P., Lemos, M., Maistro, E.L., Leite, M.F., Sousa, J.P.B., Bastos, J.K. \& de Andrade, S.F. 2008. Evaluation of antiulcer activity of the main phenolic acids found in Brazilian green propolis. Journal of Ethnopharmacology 120(3): 372377.

Garcia-Viguera, C., Ferreres, F. \& Tomas-Barberan, F.A. 1993. Study of Canadian propolis by GC-MS and HPLC.Zeitschrift für Naturforschung C 48(9-10): 731-735.

Ghisalberti,E.L. 1979. Propolis: A review.Bee World 60(2): 59-84.

Gregoris, E., Fabris, S., Bertelle, M., Grassato, L. \& Stevanato, R. 2011. Propolis as potential cosmeceutical sunscreen agent for its combined photoprotective and antioxidant properties. International Journal of Pharmaceutics 405(1): 97-101.

Hegazi, A.G., El-Hady, F.K.A. \& Abd Allah, F.A.M. 2000. Chemical composition and antimicrobial activity of European propolis. Zeitschrift fur Naturforschung C 55(1/2): 70-75.

Huang, M., Lu, J-J., Huang, M-Q., Bao, J-L., Chen, X-P. \& Wang, Y-T. 2012. Terpenoids: Natural products for cancer therapy. Expert Opinion on Investigational Drugs 21(12): 1801-1818.

Huang, S., Zhang, C-P., Wang, K., Li, G.Q. \& Hu, F-L. 2014. Recent advances in the chemical composition of propolis. Molecules 19(12): 19610-19632.

Hübschmann, H-J. 2015. Handbook of GC-MS: Fundamentals and Applications. New York: John Wiley \& Sons.

Nurhamizah Ibrahim, Nurul Farah Shakila Mohd Niza, Muhammad Muslim Mohd Rodi, Abdul Jamil Zakaria, Zhari Ismail \&
Khamsah Suryati Mohd. 2016. Chemical and biological analyses of Malaysian stingless bee propolis extracts Malaysian Journal of Analytical Sciences 20(2): 413-422.

Jacob, A., Parolia, A., Pau, A. \& Amalraj, F.D. 2015. The effects of Malaysian propolis and Brazilian red propolis on connective tissue fibroblasts in the wound healing process. BMC Complementary and Alternative Medicine 15(1): 294.

Murat Kartal, Serdar Kaya \& Semra Kurucu. 2002. GC-MS analysis of propolis samples from two different regions of Turkey. Zeitschrift fur Naturforschung C-Journal of Biosciences 57(9-10): 905-909.

Krell, R. 1996. Value-added Products from Beekeeping: Food \& Agriculture Org. http://www.fao.org/docrep/w0076e/ w0076e00.htm.

Li, F., Awale, S., Zhang, H., Tezuka, Y., Esumi, H. \& Kadota, S. 2009. Chemical constituents of propolis from Myanmar and their preferential cytotoxicity against a human pancreatic cancer cell line. Journal of Natural Products 72(7): 1283-1287.

Machado, J.L., Martins Assunçao, A.K., Pinto da Silva, M.C., dos Reis, A.S., Costa, G.C., de Sousa Arruda, D., Rocha, B.A., de Oliveira Lima Leite Vaz, M.M., de Andrade Paes, A.M., Guerra, R.N.M.,Berretta,A.A. \& do Nascimento, F.R.F. 2012 Brazilian green propolis: Anti-inflammatory property by an immunomodulatory activity. Evidence-Based Complementary and Alternative Medicine 2012: Article ID. 157652.

Maciejewicz,W., Daniewski, M., Bal, K. \& Markowski, W. 2001. GC-MS identification of the flavonoid aglycones isolated from propolis. Chromatographia 53(5-6): 343-346.

Marcucci, M.C. 1995. Propolis: Chemical composition, biological properties and therapeutic activity. Apidologie 26(2): 83-99.

Marquez Hernandez, I., Osmany, C-R., Fernandez, M.C., Perez, A.R., de Oca Porto, R.M.,Piccinelli, A.L. \& Rastrelli,L. 2010. Studies on the constituents of yellow Cuban propolis: GCMS determination of triterpenoids and flavonoids. Journal of Agricultural and Food Chemistry 58(8): 4725-4730.

McNair, H.M. \& Miller, J.M. 2011. Basic Gas Chromatography. New York: John Wiley \& Sons.

Medana, C., Carbone, F., Aigotti, R., Appendino, G. \& Baiocchi, C. 2008. Selective analysis of phenolic compounds in propolis by HPLC-MS/MS. Phytochemical Analysis 19(1): 32-39.

Melliou, E., Stratis, E. \& Chinou, I. 2007. Volatile constituents of propolis from various regions of Greece-Antimicrobial activity. Food Chemistry 103(2): 375-380.

Naito, Yukiko, Misao Yasumuro, Keiichiro Kondou \& Naoki Ohara. 2007. Antiinflammatory effect of topically applied propolis extract in carrageenan-induced rat hind paw edema. Phytotherapy Research 21(5): 452-456.

Nakajima, Yoshimi, Masamitsu Shimazawa, Satoshi Mishima \& Hideaki Hara. 2007. Water extract of propolis and its main constituents, caffeoylquinic acid derivatives, exert neuroprotective effects via antioxidant actions. Life Sciences 80(4): 370-377.

Nik Yusliyana Nik Yusoff, Suharni Mohamad, Haswati@ Nurhayati Abdullah, Nurhayu Ab Rahman, Kumitaa Theva Das, Khoirulzariah Ismail, Dasmawati Mohamad, Siti Noor Fazliah Mohd Noor, Siti Razila Abdul Razak \& Muggundha Raaov Ramachandran. 2016. Antifungal activity of Malaysian honey and propolis extracts against pathogens implicated in denture stomatitis. Paper read at AIP Conference Proceedings.

Nur Liyana Rosli, Husniyati Roslan, Eshaifol Azam Omar, Norehan Mokhtar, Nor Hussaini Abdul Hapit, Nornaimah Asem, Kumitaa Theva Das, Khoirulzariah Ismail, Dasmawati Mohamad \& Siti Noor Fazliah Mohd Noor. 2016. Phytochemical 
analysis and antioxidant activities of Trigona apicalis propolis extract. Paper read at AIP Conference Proceedings.

Osmany, C-R.,Piccinelli,A.L., Fernandez, M.C., Hernandez,I.M., Rosado, A. \& Rastrelli,L. 2007. Chemical characterization of Cuban propolis by HPLC-PDA, HPLC-MS, and NMR: The brown, red, and yellow Cuban varieties of propolis. Journal of Agricultural and Food Chemistry 55(18): 7502-7509.

Paintz, M. \& Metzner, J. 1979. On the local anaesthetic action of propolis and some of its constituents. Die Pharmazie 34(12): 839-841.

Park, Y.K., Alencar, S.M. \& Aguiar, C.L. 2002. Botanical origin and chemical composition of Brazilian propolis. Journal of Agricultural and Food Chemistry 50(9): 2502-2506.

Park, Y.K., Paredes-Guzman, J.F., Aguiar, C.L., Alencar, S.M. \& Fujiwara, F.Y. 2004. Chemical constituents in Baccharis dracunculifolia as the main botanical origin of southeastern Brazilian propolis. Journal of Agricultural and Food Chemistry 52(5): 1100-1103.

Paulino, N., Barbosa, A.P., Paulino, A.S. \& Marcucci, M.C. 2014. Hepatoprotective effect of green propolis is related with antioxidant action in vivo and in vitro. Oxidants and Antioxidants in Medical Science 3(1): 43-50.

Popova, M., Trusheva, B., Cutajar, S., Antonova, D., Mifsud, D., Farrugia, C. \& Bankova, V. 2012. Identification of the plant origin of the botanical biomarkers of Mediterranean type propolis. Natural Product Communications 7(5): 569-570.

Popova, M., Trusheva, B., Antonova, D., Cutajar, S., Mifsud, D., Farrugia, C., Tsvetkova, I., Najdenski,H. \& Bankova, V. 2011. The specific chemical profile of Mediterranean propolis from Malta. Food Chemistry 126(3): 1431-1435.

Popova, M.P., Graikou, K., Chinou, I. \& Bankova, V.S. 2010. GC-MS profiling of diterpene compounds in Mediterranean propolis from Greece. Journal of Agricultural and Food Chemistry 58(5): 3167-3176.

Shimazawa, M., Chikamatsu, S., Morimoto, N., Mishima, S., Nagai, H. \& Hara, H. 2005. Neuroprotection by Brazilian green propolis against in vitro and in vivo ischemic neuronal damage. Evidence-Based Complementary and Alternative Medicine 2(2): 201-207.

Shiva Mohammadzadeh, Mohammad Shariatpanahi, Manoochehr Hamedi, Reza Ahmadkhaniha, Nasrin Samadi \& Seyed Nasser Ostad. 2007. Chemical composition, oral toxicity and antimicrobial activity of Iranian propolis. Food Chemistry 103(4): 1097-1103.

Sobočanec, S., Balog, T., Šariċ, A., Mačak-Šafranko, Ž., Štroser, M., Žarković, K., Žarković, N., Stojković, R., Ivanković, S. \& Marotti, T. 2011. Antitumor effect of Croatian propolis as a consequence of diverse sex-related dihydropyrimidine dehydrogenase (DPD) protein expression. Phytomedicine 18(10): 852-858.

Toreti, V.C., Sato, H.H., Pastore, G.M. \& Park, Y.K. 2013. Recent progress of propolis for its biological and chemical compositions and its botanical origin. Evidence-Based Complementary and Alternative Medicine 2013: Article ID. 697390.

Trusheva, B., Popova, M., Koendhori, E.B., Tsvetkova, I., Naydenski, C. \& Bankova, V. 2011. Indonesian propolis: Chemical composition, biological activity and botanical origin . Natural Product Research 25(6): 606-613.

Volpi, N. \& Bergonzini, G. 2006. Analysis of flavonoids from propolis by on-line HPLC-electrospray mass spectrometry. Journal of Pharmaceutical and Biomedical Analysis 42(3): 354-361.
Syamsudin, Sudjaswadi Wiryowidagdo, Partomuan Simanjuntak \& Wan Lelly Heffen. 2009. Chemical composition of propolis from different regions in Java and their cytotoxic activity. American Journal of Biochemistry \& Biotechnology 5(4): 180-183.

Xuan, H., Li, Z., Yan, H., Sang, Q., Wang, K., He, Q., Wang, Y. \& $\mathrm{Hu}, \mathrm{F} .2014$. Antitumor activity of Chinese propolis in human breast cancer MCF-7 and MDA-MB-231 cells. EvidenceBased Complementary and Alternative Medicine 2014: Article ID. 280120

Yildirim, A., Duran, G.G., Duran, N., Jenedi, K., Bolgul, B.S., Miraloglu, M. \& Muz, M. 2016. Antiviral activity of Hatay propolis against replication of herpes simplex virus type 1 and type 2. Medical Science Monitor: International Medical Journal of Experimental and Clinical Research 22: 422-430.

Zayyanu Usman Umar, Abu Bakar Ainul Bahiyah \& Mohamed Mahaneem. 2016. Phytochemical screening and comparison of antioxidant activity of water and ethanol extract propolis from Malaysia. International Journal of Pharmacy and Pharmaceutical Sciences 8(5): 413-415.

Zayyanu Usman Umar, Ainul Bahiyah Abu Bakar \& Mahaneem Mohamed. 2016. Phytochemical composition and activity against hyperglycaemia of Malaysian propolis in diabetic rats. Biomedical Research 27(1).

Zayyanu Usman Umar \& Mahaneem Mohamed. 2015. Analysis of phytochemical compounds in water and ethanol extracts of Malaysian propolis. International Journal of Pharma and Bio Sciences 6(2): P374-P380.

Zhu, W., Chen, M., Shou, Q., Li, Y. \& Hu, F. 2011. Biological activities of Chinese propolis and Brazilian propolis on streptozotocin-induced type 1 diabetes mellitus in rats Evidence-Based Complementary and Alternative Medicine 2011: Article ID. 468529.

Tuan Nadrah Naim Tuan Ismail \& Kannan Thirumulu Ponnuraj School of Dental Sciences

Universiti Sains Malaysia

16150 Kubang Kerian, Kelantan Darul Naim Malaysia

Siti Amrah Sulaiman \& Norul Badriah Hassan* Department of Pharmacology, School of Medical Sciences Universiti Sains Malaysia 16150 Kubang Kerian, Kelantan Darul Naim Malaysia

Kannan Thirumulu Ponnuraj

Human Genome Centre, School of Medical Sciences

Universiti Sains Malaysia

16150 Kubang Kerian, Kelantan Darul Naim

Malaysia

Che Nin Man

National Poison Centre

Universiti Sains Malaysia

11800 Penang, Pulau Pinang

Malaysia

*Corresponding author; email: norul@usm.my

Received: 27 March 2015

Accepted: 7 June 2017 